\begin{tabular}{ll} 
Security & \\
\hline $327.36(497-15)$ & original scientific article
\end{tabular}

\title{
HUMAN SECURITY AS A BASIS OF A NEW REGIONAL SECURITY INITIATIVE
}

\section{ЧОВЕКОВА БЕЗБЕДНОСТ КАКО ОСНОВА НА НОВА РЕГИОНАЛНА БЕЗБЕДНОСНА ИНИЦИЈАТИВА}

\author{
Stefan Lakušić, MA \\ Humanistic Studies, University of Donja Gorica, Montenegro \\ E - mail: stefan.lakusic@udg.edu.me
}

\begin{abstract}
The paper tries to examine the possibility of using the human security paradigm as concept that would serve as basis of a new regional initiative in the Western Balkans region. Having in mind the turbulences of the past, as well as current cooperation flaws, the paper tries to answer the question if the establishment of this kind of initiative would be fruitful and what conditions are to be met for this initiative to start and carry out its activities. Therefore, in order to answer this basic question, the question: "What are the key elements of the human security concept? "is answered in the first phase. This is done by analyzing the doctrinal and institutional framework of this concept predominantly through relevant UN document. The content analysis method is applied. After that, the application of human security concept by several actors, including states, international organizations, funds and initiatives, is analyzed. This is done in order to establish what kind of experience exists regarding the application of this concept. The deduction and narrative methods are used in this phase. After that, based on the human security definition and analyzed praxis, the following questions are answered in the last chapter: "What are the benefits of this kind of initiative? ", "What are the preconditions to establish and successfully implement this kind of initiative? ", "What kind of approach should it implement?" Thus, the following methods are used in the last chapter: analysis and synthesis as basic methods, as well as comparative method and context analysis method as specific methods. In the concluding remarks, the author points out that the human security concept would be suitable as a theoretical basis for a new regional initiative. In the initial phases, this initiative would implement joint "soft security" or "freedom from want" projects aimed at achieving the wellbeing of individuals and
\end{abstract}


communities. The author points out that, in the long run, the implementation of this kind of projects could form a favorable ambient for the adoption of a strategic framework which would introduce directives and recommendations in order to achieve a higher level of human security in the states of the region and include even certain politicized or "freedom from fear" projects in order to achieve a holistic, human security approach. In this sense, if the region's specificities are taken into account, it is possible to build upon existing concepts, for example by positively affecting the indicators that determine the value of the Human Security Index.

Keywords: human security, individuals and communities, regional security initiative, cooperation, Western Balkans.

Апстракт: Овој труд ја истражува можноста да се употреби парадигмата на човекова безбедност (human security) како концепт кој ке служи како основа за нова регионална иницијатива за регионот на Западен Балкан. Имајќ ги предвид турбуленциите од минатото, но и сегашните проблеми во соработката, трудот се обидува да даде одговор на прашањето дали воспоставувањето на ваква иницијатива би било корисно и кои се условите кои би требало да бидат исполнети за ваквата иницијатива да отпочне и да може да ги извршува своите функции. Оттука, за да може да се даде одговор на ова централно прашање, трудот во првиот дел дава одговор на прашањето: „Кои се клучните елементи на концептот наречен човекова безбедност?” Ова е сторено преку анализа на доктриналната и институционалната рамка на овој концепт, пред се́ преку релевантните документи на $\mathrm{OH}$. Применет е метод на анализа на содржина. Потоа, трудот ја анализира примената на концептот на човекова безбедност од страна на неколку субјекти, вклучувајќи ги државите, меѓународните организации, фондови и иницијативи. Ова е преземено со цел да се покаже какво е искуството при примената на концептот на човекова безбедност во пракса. Методот на дедукција и наративност се искористени во оваа фаза. Во последниот дел од трудот, врз база на теоретската дефиниција на концептот како и анализираната практика, се дава одговор на следниве прашања: „Кои се бенефитите од овој тип на иницијатива?", "Кои се предусловите да се воспостави и успешно имплементира ваква иницијатива?" и "Каков пристап треба да се искористи за нејзино имплентирање?". Оттука, следниве методи се искористени во последното поглавје: анализа и синтеза како основни методи, но и компаративен метод и анализа на контекст, како конкретни методи. Во завршните согледувања, авторот заклучува дека концептот на човекова 
безбедност би бил соодветен како теоретска основа за нова регионална иницијатива. Во своите иницијални фази, оваа иницијатива би применувала проекти како на пример, заедничка „мека безбедност“ или „слобода од беда“, кои би целеле кон благосостојбата на индивидуите и заедниците. Авторот истакнува дека, на долг рок, имплентацијата на ваков тип на проекти би можел да доведе до формирање на погоден амбиент за усвојување на заедничка стратешка рамка, кој пак би придонела кон нови директиви и препораки со цел да се постигне едно повисоко ниво на човекова безбедност во земјите од регионот па дури и да вклучи некои политизирани или проекти како "слобода од страв", за да се постигне еден холистички пристап на човековата безбедност. Во оваа насока, а имајќ ги предвид специфичностите на регионот, авторот смета дека е можно да се искористат постоечките концепти и да се отпочне оваа иницијатива, на пример преку позитивно делување на идикаторите кои ја детерминираат вредноста на Индексот на Човекова Безбедност (Human Security Index).

Клучни зборови: човекова безбедност, индивидуи и заедници, регионална безбедносна иницијатива, соработка, Западен Балкан

\section{Introduction}

Cooperation, as a concept advocated by the predominant (neo) liberal paradigm, is widely considered a necessity in modern societies and states. However, citizens of the Western Balkans states have been witnesses of lack of cooperation in the nighties and early two thousands. Although important and substantial improvements were made, the situation is not eased by the current economic situation and uncertain political future. In this context, finding new cooperation models and arrangements seems to be a key priority issue. Thus, there is a need to consider new, emerging cooperation concepts and ideas. Indubitably, "human security" is one of those concepts.

Human security became a security studies concept with the adoption of the 1994 Human Development Report by the United Nations Development Programme (UNDP). Afterwards, the concept experienced intensive development. In this sense, the following documents made the most important contribution: UN Secretary General Report "We the Peoples: the Role of the United Nations in the $21^{\text {st }}$ Century", UN Security Council Resolution 1926, Millennium Declaration, document "Human Security Now", International 


\section{Securitity}

Commission Report "Responsibility to Protect", documents "A More Secure World: Our Shared Responsibility" and "In Larger Freedom: Towards Development, Security and Human Rights for All", as well as UN Secretary General human security reports from 2010, 2012 and 2013. ${ }^{5}$

In order to clarify the human security concept, it is necessary to start from the mentioned UNDP report. According to the document, human security can be understood in the following manner: "It means, first, safety from such chronic threats as hunger, disease and repression. And second, it means protection from sudden and hurtful disruptions in the patterns of daily life-whether in homes, in jobs or in communities". ${ }^{6}$ In accordance with this, new referent objects of security are defined - individuals and communities, while such concepts as "individual security" and "community security" become more common and influential. ${ }^{7}$

Moreover, it is particularly important to emphasize the contribution of the Commission on Human Security and its report named "Human Security Now" (2003). The Commission stance is that human security implies the following: "...to protect the vital core of all human lives in ways that enhance human freedoms and human fulfillment. Human security means protecting fundamental freedoms- freedoms that are the essence of life. It means protecting people from critical (severe) and pervasive (widespread) threats and situations". ${ }^{8}$ In accordance with this view, providing human security embraces protection of high intensity treats that endanger a larger number of people.

It is also very important to take into consideration UN Secretary General 2010 Report on human security. This document gives overview of the concept characteristics by

\footnotetext{
${ }^{5}$ Although not every of these documents refer directly to human security, every one of them has significant similarities with the concept and brings new value in its understanding.

${ }^{6}$ United Nations Development Programme, Human Development Report 1994, (New York: Oxford University Press, 1994), 23,

http://hdr.undp.org/sites/default/files/reports/255/hdr 1994 en complete nostats.pdf. Accessed on: $1^{\text {st }}$ August 2015.

7 Pauline Kerr, "Ljudska sigurnost," in Suvremene sigurnosne studije, ed. Alan Kolins (Zagreb: Politička kultura, 2010), 104, 105.

${ }^{8}$ Commission on Human Security, Human Security Now, (New York, 2003), 4, http://reliefweb.int/sites/reliefweb.int/files/resources/91BAEEDBA50C6907C1256D19006A9353chs-security-may03.pdf
} 
referring to the most important human security related documents and papers up to date. Its paragraph 19 stipulates the following human security characteristics: "First, human security is in response to current and emerging threats - threats that are multiple, complex and interrelated and can acquire transnational dimensions. Second, human security calls for an expanded understanding of security where the protection and empowerment of people form the basis and the purpose of security. Third, human security does not entail the use of force against the sovereignty of States and aims to integrate the goals of freedom from fear, freedom from want and freedom to live in dignity through people-centered, comprehensive, context-specific and preventive strategies". ${ }^{[9]}[10]$

As a broad and developing concept, it can be said than human security has no compactness. Two fundamental approaches can be noticed with significant differences between and within them:

1. Broader approach - this conception encompasses both the freedom from fear and freedom of want

2. Narrower approach - it focuses mainly on the freedom from fear

Thus, the first approach includes, besides protection from (political) violence, protection from a variety of threats and risks: epidemics/pandemics, natural technological and technical incidents and catastrophes, mass migration, economic crisis, deepening of social differences, environment deterioration etc. This approach has much in common with the original UNDP concept. Keith Kraus points out two deficiencies of this approach: its comprehensiveness and, thus, analytical uselessness and operational inapplicability, as well as unclear need of securitizing such a great number of threats in order to accomplish freedom from want. ${ }^{11}$ There are also views which advocate its operational sustainability provided that the "threshold-based definition" is adopted: "Rather than viewing human security as a list of threats, all of which must at all times be considered security issues,

\footnotetext{
${ }^{9}$ United Nations General Assembly, Human Security Report of the Secretary General, A/64/701, (8 March 2010), 6, http://responsibilitytoprotect.org/Human\%20Security\%20Report\%202010.pdf, Accessed on: $2^{\text {nd }}$ August 2015.

${ }^{10}$ The paper's goal is not to present every definition and aspect of human security. In order to have that kind of outcome, a special study would be required.

${ }^{11}$ Keith Krause, Towards a Practical Human Security Agenda, (Geneva: Geneva Centre for Democratic Control of Armed Forces, Policy Paper No. 26, 2007), 4, 5.
} 
the concept could instead be viewed in terms of a threshold, so that any threat in any location passing this threshold could become a security threat." ${ }^{\text {"12 }}$

On the other hand, the narrower approach is usually considered as more operational and providing a better public policy framework. ${ }^{13}$ This approach offers different prevention, crisis management and post-conflict peace building mechanisms. Thus, although challenges, risks and threats remain similar with the traditional, statecentric approach, the referent object is what makes the difference, which consequently leads to different mechanisms and procedures in order to attain security. It can be argued that this approach does not have comprehensiveness and, thus, departs from the core of the concept advocated by UNDP. Before giving an answer to the possible questions: "Which approach would better suit a regional human security initiative?" it is necessary to point out the national and international experiences so far.

\section{Human security in praxis - states, regional and international actors}

Nowadays there are a significant number of countries that (to a certain extent) adopted a human security approach. The best known among them are Canada and Japan.

Canada's approach has its roots in the mid nighties when its Minister of Foreign Affairs Lloyd Axworthy proclaimed human security as a foreign policy framework. If early proclamations are put aside, it can be noticed that Canada adopted a narrow, conflictfocused interpretation because it gives "the greatest added value". ${ }^{14}$ Canada participated in the formulation of the Ottawa Anti-Personnel Mine Ban Convention (1998) which could be the most significant accomplishment of its human security approach.

Japan's approach has much more in common with the broader concept. It was introduced by Prime Minister of Japan Keizo Obuchi in 1998. The Asian economic crisis in

\footnotetext{
${ }^{12}$ Mary Martin and Taylor Owen, Second generation of human security: lessons from UN and EU experience, in International Affairs (Blackwell Publishing Ltd/The Royal Institute of International Affairs, 2010), 221.

${ }^{13}$ Not all authors support this stance. See: Des Gasper, The Idea of Human Security (The Hague: Institute for Social Studies, 2008), 26, 27.

${ }^{14}$ Sabina Alkire, A Conceptual Framework of Human Security, (Centre of Research on Inequality, Human Security and Ethnicity, CRISE, Queen Elizabeth House, University of Oxford, 2003), 21.
} 


\section{Securitity}

1997 is usually seen as a key incentive factor for such an orientation. ${ }^{15}$ Japan supported the establishment of United Nations Trust Fund for Human Security (UNTFHS) in 1999, advocated the establishment of Advisory Board on Human Security designed to advice UN Security General on the management of UNTFHS, initiated the Commission on Human Security whose final report "Human Security Now"promoted a holistic security concept. It can be said that Japan promotes this concept in three ways: making policy speeches and organizing symposia, engaging other countries on human security in bilateral and multilateral meetings and referring to human security in the outcome documents of such meetings, establishing groups aiming to mainstream human security. ${ }^{16}$

Despite the obvious differences between Canada and Japan, the two have in common the fact that human security was used predominantly as foreign policy framework in order to legitimize certain policy preferences, create, and promote a "soft power" security identity. On the other hand, some countries adopted a human security framework for internal, domestic purposes. Mongolia is a good example. The country's government adopted a strategy document named "Good Governance for Human Security: Policy Document" in 2001. The document envisioned 11 rather broad objectives ${ }^{17}$ to be carried out in collaboration between the Government, the private sector and civil society. Although some significant steps were taken, the program is seen more as a broad framework for operational guidelines that are still to be designed than a program per se. $^{18}$

Moreover, certain steps towards the human security approach were made in Ecuador and Thailand. The first included human security in its constitution (2008) ${ }_{1}^{19}$ but

${ }^{15}$ Eric Remacle, Approaches to Human Security: Japan, Canada, and Europe in Comparative Perspective, (The Journal of Social Science, 2008), 7.

${ }^{16}$ The Trust Fund for Human Security, For the "Human-Centered" 2Pt Century, (Global Issues Cooperation Division, Ministry of Foreign Affairs of Japan, August 2009), 2, http://www.mofa.go.jp/policy/human_secu/t_fund21.pdf.

${ }^{17}$ See: United Nations Development Programme, Assestment of Development Results, Evaluation of UNDP Contribution, Mongolia, (March 2011), 15, 16, http://www.oecd.org/countries/mongolia/48341570.pdf, Accessed on $3^{\text {rd }}$ August 2015.

${ }^{18}$ Ibid, 16.

${ }^{19}$ United Nations General Assembly, Follow-up to General Assembly resolution 66/290 on human security, Report of the Secretary-General, A/68/685, (23 December 2013), 4, http://www.un.org/en/ga/president/68/pdf/S-G_Report_on_Human_Security_A-68-685.pdf. 
no operational plans were made based on this concept besides the UNTFHS project aimed at strengthening local capacities for peace and development in the northern border zone of Ecuador. The last established the Ministry of Social Development and Human Security in 2002 that promotes human security approach as a tool to identify priorities. This approach has three key elements: self-reliance, community empowerment, and devotion to society. ${ }^{20}$

At the regional level, the most interesting example is the Pacific Islands Forum, an international organization with 16 member states. ${ }^{21}$ The Forum adopted The Human Security Framework for the Pacific 2012-2015 in June 2012: "The aim of the Framework is to provide a clear common foundation and strategic guidance to Forum Island Countries, the Secretariat and other stakeholders for improving the understanding, planning and implementation of human security approaches in stand-alone and broader peace, security and development initiatives in the unique Pacific context. ${ }^{22}$ Member states, the Secretariat and other actors who aim to promote human security in the region are invited to adhere to the following action principles: preventive, localized, collaborative, peoplecentered, and inclusive. The Framework also stipulates five elements: political security, economic security, community, family and personal security, environmental security and social fulfillment. Precise, operative steps are not determined by the Framework, but examples of possible actions are given. Having in mind that the indicators, which determine the impact of the Framework and progress towards human security, are yet to be examined, we can conclude that the human security agenda is still at its beginning in this region. Nonetheless, the adoption of a strategic framework and procedures of its review and improvement, give a strong impulse for its development and implementation in this region.

20 United Nations Development Program, Human Security, Today and Tomorrow, Thailand Development Report 2009, (2010), 3, http://www.undp.org/content/dam/thailand/docs/NHDR2010.pdf, Accessed on: $9^{\text {th }}$ August 2015.

${ }^{21}$ Australia, Cook Islands, Federated States of Micronesia, Fiji, Kiribati, Nauru, New Zealand, Niue, Palau, Papua New Guinea, Republic of Marshall Islands, Samoa, Solomon Islands, Tonga, Tuvalu and Vanuatu.

${ }^{22}$ Pacific Islands Forum Secreteriat, Human Security Framework, http://www.forumsec.org/pages.cfm/political-governance-security/human-security-framework/, Accessed on: $9^{\text {th }}$ August 2015. 
The Environment and Security Initiative (ENVSEC) also operates at the regional level. It is a partnership of six international organizations - Organization for Security and Co-operation in Europe (OSCE), Regional Environment Centre for Central and Eastern Europe (REC), United Nations Development Programme, United Nations Economic Commission for Europe (UNECE), United Nations Environment Programme (UNEP), and the North Atlantic Treaty Organization (NATO) as an associated partner. ENVSEC aims to help governments and communities to identify common solutions and develop joint projects. This approach includes mechanisms, which address links between the natural environment and human security. ${ }^{23}$ It helped the implementation of 150 projects in four regions - Central Asia, Eastern Europe, Southern Caucasus, and South-Eastern Europe. However, it can be argued that this initiative does not have a holistic approach, but focuses predominantly on environmental issues.

Perhaps the most prominent human security approach can be observed at the international level - The United Nations Trust Fund for Human Security. Based on the General Assembly Resolution 66/290 (2012) which recognizes as an approach suitable for identifying and addressing widespread and crosscutting challenges, ${ }^{24}$ the Fund was established by the Government of Japan and UN Secretariat in 1999. Since 2004, it is administered by the Human Security Unit (HSU), which operates within the UN system. It has the four goals: to underscore the importance of human security for all, to respond to different situations of human insecurity, to develop practical tools, and to disseminate lessons learned and foster collaboration. ${ }^{25}$ HSU operates within its Strategic Plan (20142017) with special attention paid to the role of UNTFHS and its projects. By 2014 UNTFHS has realized more than 210 projects worldwide: "Projects have succeeded in rebuilding war-torn communities; protecting people exposed to extreme poverty, sudden economic

23 The Environment and Security Initiative, Transforming risks into Cooperation, http://www.envsec.org/index.php?lang=en, Accessed on: $12^{\text {th }}$ August 2015.

24 United Nations, General Assembly, Resolution Adopted by the General Assembly on 10 September 2012, Follow-up to paragraph 143 on human security of 2005 World Summit Outcome, A/RES/66/290, (25 October 2010),

http://www.un.org/humansecurity/sites/www.un.org.humansecurity/files/hsu\%20documents/GA\% 20Resolutions.pdf, Accessed on: $12^{\text {th }}$ August 2015.

25 United Nations Human Security Fund, About Human Security Unit, url: http://www.un.org/humansecurity/human-security-unit/about-human-security-unit-0, Accessed on: $13^{\text {th }}$ August 2015. 


\section{Securitity}

downturns and natural disasters; and addressing urban violence, trafficking in persons, arms and illicit substances; among others." ${ }^{26}$

Besides the mentioned examples, many other subjects, including states, international organizations, NGOs, groups, forums, initiatives, etc, promoted human security. Nonetheless, great majority of these subjects does not use this concept as an internal policy framework, but more as a foreign policy tool, a base for a security identity or a concept used for lobbying purposes.

\section{Human Security as a framework for the Western Balkans}

Various forms of political and economic instability in Western Balkans countries ${ }^{27}$ have made cooperation impossible at the end of the twentieth century. As a response to those circumstances, various forms of regional initiatives were promoted in order to foster conciliation and rapprochement. ${ }^{28}$ The majority of those initiatives was introduced by the West and, consequently, had European and Euroatlantic standards as a main idea and policy framework. This idea was productive to a certain extent and the majority of authors agree that significant improvement was made as far as the security situation in the region and overall regional cooperation. However, this idea drives its force from external models. Recognizing the value of these models and standards, the region could go further by adopting a human security approach as a base of a local owned initiative and develop cooperation driven by internal forces based on universal ideas and principles.

26 United Nations Human Security Fund, Trust Fund Achievements around the World, url: http://www.un.org/humansecurity/trust-fund, Accessed on: $13^{\text {th }}$ August 2015.

${ }^{27}$ The term "Western Balkans" refers to countries that emerged from ex-Yugoslavia minus Slovenia plus Albania.

${ }^{28}$ Among others, the following regional security initiatives were established: South-East Europe Cooperation Process (SEECP), South-East Europe Initiative (SEEI), U.S - Adriatic Charter, South Eastern Defence Ministerial (SEDM), Southeast Europe Clearinghouse (SEEC), Regional Arms Control Verification and Implementation Assistance Centre (RACVIAC), Regional Center for Combating Transbording Crime (SECI), Disaster Preparation and Prevention Initiative for SouthEastern Europe (DPPISEE), Regional Anticorruption Initiative (RAI), Police Convention on South Eastern Europe (PCC SEE), Southeast European Police Chiefs Association (SEPCA). See: Mehmedin Tahirović, "Regionalne bezbjednosne inicijative", in Crna Cora u XXI stoljeću - u eri kompetitivnosti, Integracija u evropske i evroatlantske strukture, ed. Cordana Đurović (Podgorica: Crnogorska akademija nauka i umjetnosti, 2010), 122-134. 


\section{Securitity}

Although such an idea may seem idealistic or utopist, it can be argued that, its inception and effective functioning may be easier to accomplish that it may appear.

Firstly, the rooted argument that Western Balkan region is "immune" to (unforced) collaboration must be rejected. If only the experiences before the exYugoslavia wars are taken into consideration, many examples from the previous century can confirm this stance: alliances during Balkan wars and World War One, the formation of Kingdom of Serbs, Croats and Slovenians, Balkan Conferences (1930-1933), Balkan Pact Agreement (1934), formation of Democratic Federative Yugoslavia (1943-45) and Federative Peoples Republic of Yugoslavia (1945-63), Agreement of Friendship and Cooperation (1953), Balkan Countries Foreign Ministers Conferences (1988-90), etc. ${ }^{29}$

Secondly, the analyzed cases, especially UNFHS and ENVSEC testify that a human security approach can be adopted and function effectively. These organizations carried out a vast number of projects aimed at improving individual and community security.

Thirdly, common criticism that human security framework does not provide any concrete indicators to measure the level of human security. This argument has already been called severely into question by the release of Human Security Index (HSI) reports in 2008 and 2010. HSI covers 232 countries and considers more than 30 leading economic indicators. If such an index can be measured for 232 , it can also be done, even with much more relevant indicators, for a small group of Western Balkan countries. Moreover, since priority would be given to improvement of most concerning indicators, the usual narrow/broad approach dilemma loses its importance.

Fourthly, the lack of experience for this kind of initiative in the region can impose a challenge only to a certain extent. The initiative would not start ex nihilo, but built upon the mentioned experiences, including the projects carried out by UNFHS ${ }^{30}$ and ENVSEC. ${ }^{31}$ The experiences of the Regional Cooperation Council (RCC) would also be taken in consideration, not only as a locally owned initiative, but also as an initiative that develops

${ }^{29}$ Duško Lopandić, Jasminka Kronja, Regionalne inicijative i multilateralna saradnja na Balkanu, (Beograd: Evropski pokret u Srbiji, 2010), 33-54.

${ }^{30}$ UNTFHS has 18 completed/on-going projects in the Western Balkans region.

${ }^{31}$ ENVSEC has more than 30 completed/on-going projects in the Western Balkans region. Some of these projects include the participation of non-Western Balkans states. 
regional strategies, most notably "South East Europe 2020" which gives a policy framework, precise objectives and implementation instruments as well as mechanisms of governance and monitoring.

It can be argued that there are no serious methodological or technical obstacles to start such an initiative. Nonetheless, political will and financial resources are a necessary precondition of its inception and functioning. In this context, it is easy to predict that certain types of projects necessary for the improvement of human security indicators would not have the support of national political elites. Thus, the initiative would have to concentrate, at least in the short run, on projects, which do not have political implications. Some types of economic, social, environmental and health care projects could be suitable, while governance and minority rights issues could be put aside. This kind of projects would be certainly welcomed by the targeted communities, while the sovereignty of states would not be jeopardized. If the governments could directly support this, the initiative could start as an international NGO. As far as financial resources, besides regional contributions, this kind of initiative would certainly be welcomed by UN and its agencies, UNTFHS and developed states that advocate the human security approach. In the short run, some kinds of quotas would be suitable in order to assure that donated funds do not significantly transfer from one country to another.

In the end the implementation of this kind of projects could form a favorable ambient for the adoption of a strategic framework which would introduce directives and recommendations in order to achieve a higher level of human security in the Western Balkans states. Over time, this framework could include certain kinds of political projects. If the initiative is guided impartially and responsibly (which could be the biggest challenge for such a subject), this initiative could not just improve life conditions, but also substantially improve international relations among the Western Balkans states. As distant as it may seem, we have to have in mind that human security is a concept that is gaining more and more support not just as a discourse, but also as a policy framework. It is a modern, progressive and useful concept, which drives its strength not just from documents and doctrines, but also from its emancipatory postulates, which do not focus, on states, but on universal categories - individuals and communities. Although it would be delusional to expect the world powers to adopt it in the short run, it could be suitable for small states as the Western Balkans region ones. 


\section{Conclusion}

Since its inception in 1994, the human security concept has elaborated in several directions by several authors. However, it is most important and referent explications were given in several UN documents, with the UN Secretary General human security reports giving the most complete overview.

Over time, this concept has risen from a mere proclamation to an important policy framework tool. While some developed states, such as Canada and Japan, use it predominantly for foreign policy purposes, some states, regional and international organizations use it as a framework for identifying and addressing internal challenges. Mongolia, Ecuador and Thailand are included in the group of states that use such a framework, while the Pacific Islands Forum, ENVSEC and UNFHS are international organizations what use such an approach.

Having in mind this kind of global context as well as the complex challenges that are still present in the Western Balkans states, the eligibility a human security approach cannot be questioned. The concept should not be seen as a replacement for a statecentric one, neither as a threat to European and Euroatlantic values and discourses, but rather as a complementary framework.

Although the adoption of such new practices may seem idealistic, it can be argued that, as far as previous experience, applicability and improvement measurement criteria, there are no substantial obstacles. The main preconditions, such as political will and financial resources could be realized through a regional human security initiative. In its beginning, phases sensitive, political issues would not be at the table, but the most prominent "soft security" challenges would be addressed.

In the end, this initiative would be beneficial not just for the projects' targeted groups, but for whole societies by fostering substantial rapprochement, reconciliation and mutual trust. Perhaps even more importantly, this initiative could contribute to a new culture of international relations among the Western Balkans states. Indubitably, activities driven by internal forces would make a solid base for genuine cooperation and permanent stability in the region.

To many times the region has been one-step behind. Maybe it is time to be onestep ahead. 


\section{Bibliography}

\section{Books and articles}

1. Acharya, Amitav, Human Security, East versus West. Toronto: Canadian International Council, 2001.

2. Alkire, Sabina, A Conceptual Framework of Human Security. Centre of Research on Inequality, Human Security and Ethnicity, CRISE, Queen Elizabeth House, University of Oxford, 2003.

3. Brauch, Hans Gunter, Reconceptualization of Security and Regional Dimension of UN Activities: Towards a Mediterranean Environmental and Human Security Initiative in The United Nations and the Regions, edited by Philippe de Lombaerde, Francis Baert and Tania Felicio. London, New York: Springer, 2012.

4. Gasper, Des, The Idea of Human Security. The Hague: Institute for Social Studies, 2008.

5. Kerr, Pauline, "Ljudska sigurnost," in Suvremene sigurnosne studije, edited by Alan Kolins. Zagreb: Politička kultura, 2010.

6. Krause, Keith, Towards a Practical Human Security Agenda. Geneva: Geneva Centre for Democratic Control of Armed Forces, Policy Paper No. 26, 2007.

7. Lopandić, Duško and Kronja, Jasminka, Regionalne inicijative i multilateralna saradnja na Balkanu. Beograd: Evropski pokret u Srbiji, 2010.

8. Martin, Mary and Owen, Taylor, Second generation of human security: lessons from UN and EU experience, in International Affairs. Blackwell Publishing Ltd/The Royal Institute of International Affairs, 2010.

9. Owen, Taylor, The Uncertain Future of Human Security in the UN. UNESCO, 2008.

10. Remacle, Eric, Approaches to Human Security: Japan, Canada, and Europe in Comparative Perspective. The Journal of Social Science, 2008.

11. Tahirović, Mehmedin, "Regionalne bezbjednosne inicijative", in Crna Gora u XXI stoljeću - u eri kompetitivnosti, Integracija u evropske i evroatlantske strukture, edited by Gordana Đurović, 122-134. Podgorica: Crnogorska akademija nauka i umjetnosti, 2010. 


\section{Documents}

1. Commission on Human Security, Human Security Now. New York: 2003. http://reliefweb.int/sites/reliefweb.int/files/resources/91BAEEDBA50C6907 C1256D19006A9353-chs-security-may03.pdf.

2. Human Security Unit, Strategic Plan 2014-2017. New York: United Nations, 2014.http://www.un.org/humansecurity/sites/www.un.org.humansecurity/fil es/HSU\%20Strategic\%20Plan\%202014-2017\%20Web\%20Version.pdf.

3. International Commission on Intervention and State Sovereignty, The Responsibility to Protect. Ottawa: International Development Research Centre, 2001. http://responsibilitytoprotect.org/ICISS\%20Report.pdf.

4. Kofi A. Annan, Secretary-General of the United Nations, We the peoples: the role of the United Nations in the twenty-first century. New York: United

5. Nations Department of Public Information, 2000. http://www.un.org/en/events/pastevents/pdfs/We_The_Peoples.pdf.

6. The Trust Fund for Human Security, For the "Human-Centered" 21st Century. Clobal Issues Cooperation Division, Ministry of Foreign Affairs of Japan, August 2009. http://www.mofa.go.jp/policy/human secu/t fund21.pdf.

7. Secretary's General High-Panel on Threats, Challenges and Change, A more secure world: Our shared responsibility. New York: United Nations, 2004. http://www.un.org/en/peacebuilding/pdf/historical/hlp_more_secure_world. pdf

8. United Nations Development Programme, Assessment of Development Results, Evaluation of UNDP Contribution, Mongolia. March 2011. http://www.oecd.org/countries/mongolia/48341570.pdf.

9. United Nations Development Programme, Human Development Report 1994, New York: Oxford University Press, 1994.

http://hdr.undp.org/sites/default/files/reports/255/hdr_1994_en_complete _nostats.pdf.

10. United Nations Development Program, Human Security, Today and Tomorrow, Thailand Development Report 2009. 2010. http://www.undp.org/content/dam/thailand/docs/NHDR2010.pdf.

11. United Nations General Assembly, Human Security Report of the Secretary General, A/64/701. 8 March 2010. 
12. http:/responsibilitytoprotect.org/Human\%20Security\%20Report\%202010.pd f.

13. United Nations General Assembly, Follow-up to General Assembly resolution $66 / 290$ on human security, Report of the Secretary-General, A/68/685. 23 December 2013.

14. http://www.un.org/en/ga/president/68/pdf/SG Report on Human Securit y A-68-685.pdf.

15. United Nations General Assembly, In Larger Freedom: Towards Development, Security and Human Rights for All, Report of the Secretary General. 26 May 2005. http://www.ohchr.org/Documents/Publications/A.59.2005.Add.3.pdf.

16. United Nations General Assembly, Resolution Adopted by the General Assembly on 10 September 2012, Follow-up to paragraph 143 on human security of 2005 World Summit Outcome, A/RES/66/290. 25 October 2010. http://www.un.org/humansecurity/sites/www.un.org.humansecurity/files/hs u\%20documents/GA\%20Resolutions.pdf

17. United Nations, Security Council, Resolution 1296 (2000), S/RES/1296. http://unpan1.un.org/intradoc/groups/public/documents/un/unpan000923. pdf

\section{Websites}

1. Pacific Islands Forum Secretariat, Human Security Framework, http://www.forumsec.org/pages.cfm/political-governance-security/humansecurity-framework/.

2. The Environment and Security Initiative, Transforming risks into Cooperation, http://www.envsec.org/index.php?lang=en.

3. The Organization for Economic Co-operation and Development, Development aid stable in 2014 but flows to poorest countries still falling, http://www.oecd.org/dac/norway.htm. 